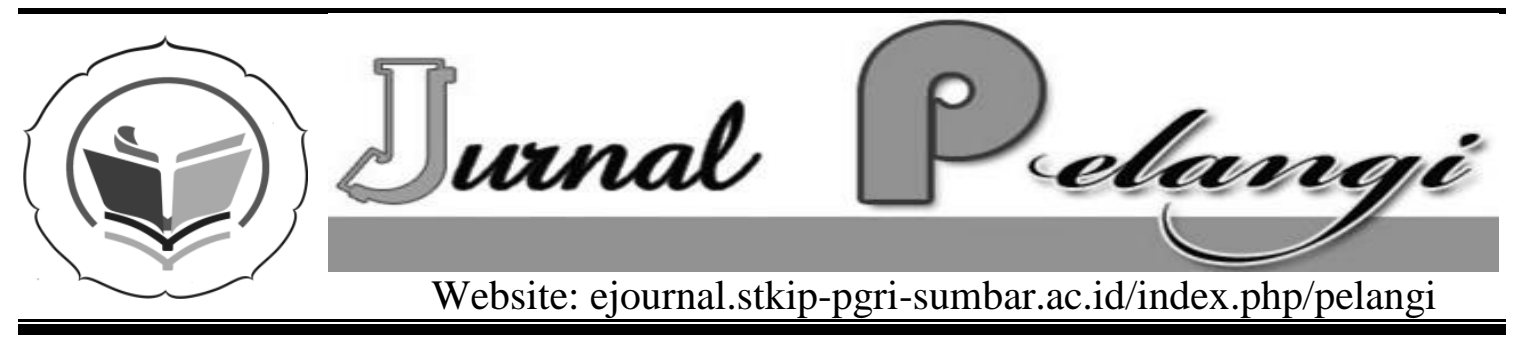

\title{
METODE DISCOVERY LEARNING PADA MATA KULIAH METODE PENELITIAN SOSIAL DI PROGRAM STUDI PENDIDIKAN SEJARAH STKIP PGRI SUMATERA BARAT
}

\author{
Zusmelia $^{1)}$, Zulfa $^{2)}$ \\ STKIP PGRI Sumatera Barat
}

INFO ARTIKEL

Diterima :01-01-2014

Disetujui :12-01-2014

Kata Kunci:

PTK, metode Discovery Learning, refleksi
Keywords:

CAR,

Discovery Learning

Method,

Reflection
Abstrak

\begin{tabular}{l}
\hline Pembelajaran mata kuliah Metode Penelitian Sosial \\
selalu mengalami kesulitan hal ini dikarenakan \\
rendahnya kreativitas mahasiswa dalam mencari dan \\
menemukan masalah. Mahasiswa lebih senang bekerja \\
sama dalam mencari permasalahan dalam perkuliahan \\
metode penelitian sosial, untuk itu dosen berusaha untuk \\
melakukan penelitian tindakan kelas (PTK). PTK yang \\
akan dilakukan adalah dengan menggunakan metode \\
Discovery Learning. Metode Discovery Learning \\
merupakan suatu model pembelajaran yang \\
dikembangkan berdasarkan pandangan konstruktivisme. \\
Model ini menekankan pentingnya pemahaman struktur \\
atau ide-ide penting terhadap suatu disiplin ilmu, \\
melalui keterlibatan siswa secara aktif dalam proses \\
pembelajaran. Pada mata kuliah metode penelitian \\
sosial mahasiswa dituntut untuk mencari dan \\
menemukan masalah dalam perkuliahan ini. Penelitian \\
ini adalah penelitian PTK (Penelitian TIndakan Kelas) \\
yaitu suatu penelitian refleksi oleh tindakan yang \\
dilakukan oleh dosen sendiri untuk memperbaiki proses \\
pembelajaran yang menjadi tanggung jawabnya.
\end{tabular}

\section{Abstract}

The learning of Social Research Method subject has always had difficulties since the low of student's creativity in seeking and finding the problem. The students prefer to cooperate in finding the problem of the subject. It is one of the reasons for the Lecturer to do a Classroom Action Research (CAR). CAR is conducted by using a Discovery Learning method. This method is a learning model developed based on the constructivism. It emphasizes the necessity of the important structures or 
ideas to a discipline by having an active student involvement in the learning process. On this subject, a student is required to seek and find out the problems. $C A R$ is a reflected research of the actions taken by the Lecturers to improve the learning process as one of their responsibilities

\section{PENDAHULUAN}

Dosen sebagai penyelenggara pendidikan sekolah khususnya, sekaligus penggerak proses belajar dituntut menguasai beberapa kompetensi baik dari segi pengetahuan keterampilan yang berkaitan dengan profesionalnya.Proses belajar mengajar yang berorientasi pada tujuan, sangat memerlukan aktivitas siswa, sebab siswa sebagai subjek didik adalah yang melakukan dan melaksanakan belajar dengan bimbingan guru..

Perlu disadari bahwa peranan dosen dalam proses pembelajaran hanya sebagai fasilator dan mediator, sedangkan yang melakukan kegiatankegiatan belajar itu sendiri adalah siswa. Oleh sebab itu guru mempunyai peranan penting dalam menyusun strategi pembelajaran dan menciptakan keaktifan siswa dalam mencapai tujuan yang telah ditentukan. Adapun faktor-faktor yang menyebabkan tidak aktifnyapeserta didik dalam belajar antara lain:

1. Dosen kurang bervariasi penyampaian materi pelajaran.

2. Dosen kurang memperhatikan keadaan karakteristik siswa.

3. Kurang tepatnya dosen dalam pemakaian media pembelajaran.
4. Dosen tidak menggunakan media, hanya menggunakan metode ceramah.

5. Dosen kurang memberikan kebebasan pada siswa untuk mengembankan ide-idenya.

Berdasarkan pengalaman dalam memberikan perkuliahan di Program Studi pendidikan Sejarahterutama mata Metode Penelitian Sosial, mahasiswa kurang termotivasi dan aktif dalam kelas.Hal ini terjadi karena cendrung mahasiswa mengharapkan materi dari dosen. Mahasiswa kurang aktif, malah cendrung pasif. Selama proses perkuliahan mahasiswa kurang bersemangat terhadap topik/materi yang dihadapi sehingga mahasiswa lebih senang bekerja sama dalam menyelesaikan tugas individu yang diberikan.Ini terbukti dengan diberikannya tugas mencari dan menemukan masalah penelitian sosial hanya 4 persen yang mencari dan mengerjakan dengan sungguhsungguh tugas yang diberikan kepada mahasiswa.

Dalam merubah proses perkuliahanmahasiswa yang cendrung pasif tersebut, diperlukan suatu strategi dan metode yang baru dan lebih memberdayakan. Suatu strategi dan metode yang bisa mendorong mahasiswa untuk belajar, 
aktif, kreatif dan meningkatkan aktivitas belajar mahasiswa., maka proses perkuliahan terutama mata kuliah Metode Penelitian sosialperlu dikemas dan disajikan dengan menarik, dan menyenangkan. Strategi yang dilakukan adalah melalui penggunaan metode Discovery Learning.Metode discovery learning dapat mengembangkan minat membaca mahasiswa dalam memahami suatu materi pelajaran yang dipelajari karena tugas tersebut akan dipertanggungjawabkan terhadap dosen serta menumbuhkan komunikasi yang efektif kekurangan tugas yang dibuat dapat saling melengkapi. Metode discovery ini cocok diterapkan untuk mata kuliah Metode Penelitian Sosial, karena metode discovery learning di sini memfokuskan pada penemuan mahasiswa dalam berbagai materi yang ditugaskan.

Berdasarkan pembatasan masalah, rumusan masalah dalam penelitian ini adalahsebagai berikut: Apakah ada pengaruh yang berarti penerapan metode discovery learning terhadap peningkatan aktivitas belajar mahasiswa pada mata kuliah Metode penelitian Sosial angkatan 2011 C di Program Studi Pendidikan Sejarah STKIP PGRI Sumatera Barat?

Belajar menurut perspektif Behavioristik adalah perubahan perilaku sebagai hasil Interaksi individu dengan lingkungannya.
Proses interaksi tersebut merupakan hubungan antara stimuli (S) dan respon (R). Muara belajar adalah terbentuknya kebiasaan. Watson mengemukakan ada dua prinsip dalam pembentukan kebiasaan yaitu kekerapan dan kebaruan. Prinsip kekerapan menyatakan bahwa makin kerap individu bertindak balas terhadap suatu stimuli, apabila kelak muncul lagi stimuli itu maka akan lebih besar kemungkinan individu memberikan respon yang sama terhadap stimuli tersebut.

Edwin Guthrie berdasarkan konsep contiguity menyatakan bahwa suatu kombinasi Stimuli yang dipasangkan dengan suatu gerakan akan diikuti oleh gerakan yang sama apabila stimuli tersebut muncul kembali. Pergerakan ini diperoleh melalui latihan. Guthrie juga mengemukakan prinsip tentang pembinaan dan perubahan kebiasaan. Pada dasarnya pembinaan dan perubahaan kebiasaan dapat dilakukan melalui threshold method (metode ambang), the fatigue method (metode meletihkan), dan the incompatible response method (metode rangsangan tidak serasi). Thorndike berpendapat bahwa belajar pada dasarnya merupakan pembinaan hubungan antara stimuli tertentu dengan respon tertentu. Semua proses belajar dilakukan dengan coba-salah (trial and error). Ada tiga hukum dalam hal tersebut yaitu (1) hukum hasil (law of effect), (2) hukum latihan (law of exercise), 
(3) hukum kesiapan (law of readiness). Skinner menyatakan bahwa peneguhan (reinforcement) memegang peran penting dalam mewujudkan tindak balas baru. Peneguhan diartikan sebagai suatu konsekuensi perilaku yang memperkuat perilaku tertentu. Kegiatan belajar mengajar berdasarkan prinsip-prinsip Behavioristik merupakan kegiatan belajar figuratif. Belajar seperti ini hanya menekankan perolehan informasi dan penambahan informasi. Belajar merupakan proses dialog imperatif, bukan dialog interaktif. Belajar bukan proses organik dan konstruktif melainkan proses mekanik. Aktivitas belajar didominasi oleh kegiatan menghafal dan latihan.

Dalam belajar sangat diperlukan aktivitas, sebab pada prinsipnya belajar adalah berbuat, untuk merubah tingkah laku, untuk melakukan sesuatu kegiatan. Tidak ada aktivitas, dengan demikian aktivitas merupakan prinsip atau azas yang sangat penting dalam interakasi belajar mengajar. Prinsip utama yang dikembangkan Prober dalam Arif Sardiman (2003)anak harus bekerja sendiri dalam belajar, ia menciptakan suatu semboyan dalam belajar harus ada berfikir dan berbuat. Kemudian Mentesori dalam Arif Sardiman (2003)menegaskan juga, bahwa anak-anak memiliki tenaga-tenaga untuk berkembang sendiri, membantu diri sendiri.
Pembimbingan tugasnya adalah untuk membimbing dan mengamati perkembangan anak didiknya, kemudian merencanakan apa yang dikerjakan anak didik. Seterusnya Rousen dalam Arif Sardiman (2001)berpendapat lagi, ia mengatakan bahwa segala pengetahuan harus diperoleh dengan pengamatan sendiri, penyelidikan sendiri dengan bekerja sendiri, dengan fasilitas yang diciptakan sendiri, baik secara rohani maupun teknis. Ia mengatakan bahwa semua orang harus aktif sendiri dalam belajar. Tanpa aktivitas dalam belajar, maka proses belajar tidak mungkin terjadi.

Berdasarkan pandangan para ahli diatas, jelas dalam belajar subjek didik aktif berbuat. Tanpa adanya aktifitas belajar, pembelajaran tidak akan berhasil dengan baik.

Penemuan

(discovery) merupakan suatu model pembelajaran yang dikembangkan berdasarkan pandangan konstruktivisme. Model ini menekankan pentingnya pemahaman struktur atau ide-ide penting terhadap suatu disiplin ilmu, melalui keterlibatan mahasiswa secara aktif dalam proses pembelajaran.

Menurut Wilcox (Slavin, 1977), dalam pembelajaran dengan penemuan mahasiswa didorong untuk belajar sebagian besar melalui keterlibatan aktif mereka sendiri dengan konsep-konsep dan prinsipprinsip, dan dosen mendorong 


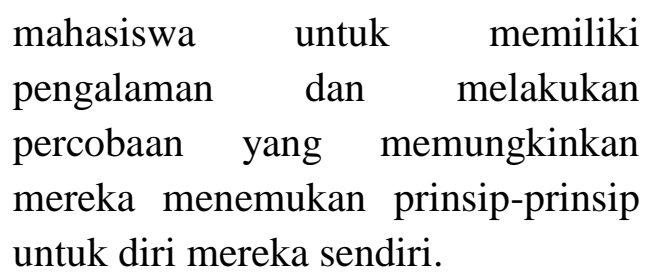

Pengertian discovery learning menurut Jerome Bruner adalah metode belajar yang mendorong mahasiswa untuk mengajukan pertanyaan dan menarik kesimpulan dari prinsip-prinsip umum praktis contoh pengalaman. Dan yang menjadi dasar ide J. Bruner ialah pendapat dari Piaget yang menyatakan bahwa anak harus berperan secara aktif didalam belajar di kelas. Untuk itu Bruner memakai cara dengan apa yang disebutnya discovery learning, yaitu mahasiswa mengorganisasikan bahan yang dipelajari dengan suatu bentuk akhir.

Pembelajaran penemuan merupakan salah satu model pembelajaran yang digunakan dalam pendekatan konstruktivis modern. Pada pembelajaran penemuan, mahasiswa didorong untuk terutama belajar sendiri melalui keterlibatan aktif dengan konsep-konsep dan prinsip-prinsip. Dosen mendorong mahasiswa agar mempunyai pengalaman dan melakukan eksperimen dengan memungkinkan mereka menemukan prinsip-prinsip atau konsep-konsep bagi diri mereka sendiri. Pembelajaran Discovery learning adalah model pembelajaran yang mengatur sedemikian rupa sehingga mahasiswa memperoleh pengetahuan yang belum diketahuinya itu tidak melalui pemberitahuan, sebagian atau seluruhnya ditemukan sendiri. Dalam pembelajaran discovery learning, mulai dari strategi sampai dengan jalan dan hasil penemuan ditentukan oleh siswa sendiri. Hal ini sejalan dengan pendapat Maier (Winddiharto:2004) yang menyatakan bahwa, apa yang ditemukan, jalan, atau proses sematamata ditemukan oleh mahasiswa sendiri.

Berdasarkan pengertian di atas dapat disimpulkan bahwa pembelajaran discovery

learning adalah suatu model untuk mengembangkan cara belajar mahasiswa aktif dengan menemukan sendiri, menyelidiki sendiri, maka hasil yang diperoleh akan setia dan tahan lama dalam ingatan, tidak akan mudah dilupakan siswa. Dengan belajar penemuan, mahasiswa juga bisa belajar berfikir analisis dan mencoba memecahkan sendiri problem yang dihadapi. Kebiasaan ini akan di transfer dalam kehidupan bermasyarakat. 


\section{Kerangka Pemikiran}

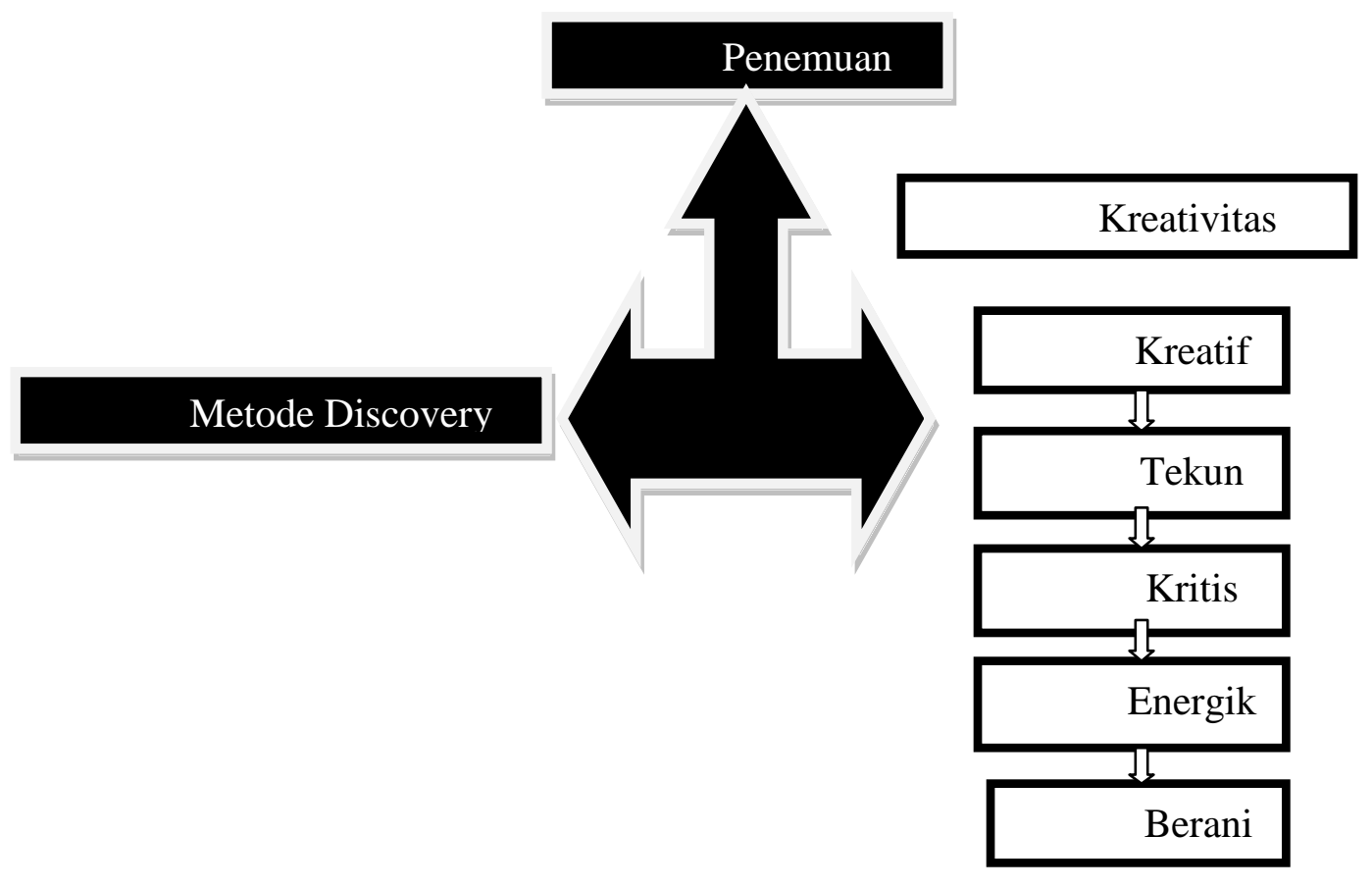

\section{METODE PENELITIAN}

Jenis penelitian yang digunakan adalah Penelitian Tindakan Kelas. Menurut Suhardjono (2008) PTK adalah penelitian tindakan yang dilakukan dengan tujuan memperbaiki mutu praktek pembelajaran dikelas 2011 C, Program Studi Pendidikan Sejarah STKIP PGRI Sumatera Barat.Penelitiandilakukan pada mahasiswa semester enam $2011 \mathrm{C}$ tahun 2014. untukmata kuliah Metode Penelitian Sosial.

\section{HASIL DAN PEMBAHASAN}

Berdasarkan analisis data observasi penelitian yang dilakukan di sesi 2011 C Prodi pendidikan Sejarah, disetiap siklus menunjukan bahwa penggunaan metode discoveri learning ini meningkatkan kreatifitas mahasiswa dalam belajar. Dari hasil observasi yang dilakukan selama dua siklus menunjukan bahwa keterlaksanaan pembelajaran

mahasiswa pada umumnya dapat di katakan baik. Dan mahasiswa juga telah menunjukan kreatifitasnyanya dalam melakukan proses kegiatan pembelajaran.

Dalam penelitian ini, peneliti menemukan beberapa hambatan, terutama dalam siklus I yg di sebabkan oleh :

1. Mahasiswa masih baru dengan pembelajaran menggunakan metode Discovery Learningsehingga 
mahasiswa masih belum sepenuhnya mengerti .

2. Kurangnya kerja sama antar mahasiswa

3. Mahasiswa masih belum percaya diri dalam menjawab pertanyaan

Pada siklus II dosen terus dan membacanya, serta dosen akan terus memberikan tambahan nilai bagi mahasiswa yg kreatif. Rata-rata peningkatan kreatifitas belajar mahasiswa pada siklus I dan siklus II dapat dilihat pada table

berikut :

memberikan dorongan supaya

mahasiswa terus membawa buku paket

Tabel 1. Rata-rata peningkatan daya kreatifitas belajar Mahasiswa pada siklus I dan siklus II

\begin{tabular}{|c|c|c|c|c|c|}
\hline \multirow{2}{*}{ No } & \multirow[t]{2}{*}{ Kreativitas } & \multicolumn{2}{|c|}{$\begin{array}{l}\text { Persentase } \\
\text { Mahasiswa }\end{array}$} & \multicolumn{2}{|l|}{ Rata-rata } \\
\hline & & Siklus I & Siklus II & Peningkatan & \\
\hline 1. & $\begin{array}{l}\text { Kreatif dalam mencari } \\
\text { dan menemukan } \\
\text { masalah }\end{array}$ & $43,3 \%$ & $75 \%$ & 31,7 & 59,15 \\
\hline 2. & $\begin{array}{l}\text { Membuat masalah sosial } \\
\text { metode kuantitatif }\end{array}$ & $31,6 \%$ & $78,3 \%$ & 46,7 & 54,95 \\
\hline 3. & $\begin{array}{l}\text { Berinisiatif mencatat } \\
\text { keterangan dosen }\end{array}$ & $37,5 \%$ & $50 \%$ & 12.5 & 43.75 \\
\hline 4. & $\begin{array}{l}\text { Berinisiatif membuat } \\
\text { kesimpulan }\end{array}$ & $28,3 \%$ & $43,3 \%$ & 15 & 35.8 \\
\hline 5. & $\begin{array}{l}\text { Tekun mendengarkan } \\
\text { keterangan dosen }\end{array}$ & $79,1 \%$ & $79.1 \%$ & 0 & 79.1 \\
\hline 6. & $\begin{array}{l}\text { Tekun memperhatikan } \\
\text { dosen yang sedang } \\
\text { menerangkan }\end{array}$ & $89.1 \%$ & $89 \%$ & -0.1 & 89,05 \\
\hline 7. & $\begin{array}{l}\text { Enerfik menanyakan } \\
\text { materi yg tdk mengerti }\end{array}$ & $18.3 \%$ & $39.1 \%$ & 20.8 & 28.7 \\
\hline 8. & $\begin{array}{l}\text { Berani mengeluarkan } \\
\text { pendapat }\end{array}$ & $30.8 \%$ & $36.6 \%$ & 5.8 & 33,7 \\
\hline 9. & $\begin{array}{l}\text { Berani bertanya kepada } \\
\text { dosen }\end{array}$ & $30.8 \%$ & $41.6 \%$ & 10.8 & 36.2 \\
\hline 10. & $\begin{array}{l}\text { Kritis memahami } \\
\text { jawaban dari teman lain }\end{array}$ & $22.5 \%$ & $38.3 \%$ & 15.8 & 30.4 \\
\hline
\end{tabular}

Berdasarkan tabel diatas, persentase kreatifitas belajar mahasiswa pada tiap siklus adalah sebagai berikut:

1. Mengerjakan soal/latihan yang diberikan dosen disekolah dengan persentase $59,15 \%$ termasuk dalam kategori Sedang

2. Mengerjakan tugas rumah dengan persentase $54,95 \%$ termasuk dalam kategori Sedang 
3. Membuat tugas individu dengan persentase $43,75 \%$ termasuk dalam kategori Sedang

4. berinisiatif mencatat keterangan dosen dengan persentase 35,8\% termasuk dalam kategori Kurang

5. Berinisiatif membuat kesimpulan dengan persentase $65,6 \%$ termasuk dalam kategori Sangat Baik

6. Tekun mendengarkan keterangan dosen dengan persentase $89.05 \%$ termasuk dalam kategori Baik

7. Tekun memperhatikan dosen yang sedang menerangkan dengan persentase $28.7 \%$ termasuk dalam kategori Kurang

8. Tekun menjawab soal/latihan dengan persentase 33,7\% termasuk dalam kategori Kurang

9. Energik menanyakan materi yang tidak tidak dimengerti dengan $36.2 \%$ termasuk dalam kategori Kurang

10. Berani mengeluarkan pendapat dengan persentase $30,4 \%$ termasuk dalam kategori Kurang

Dari hasil penelitian yang diperoleh, maka dapat dilihat bahwa telah terjadi peningkatan kreatifitas mahasiswa dalam proses pembelajaran dengan menggunakan metode Discovery Learning. Walaupun peningkatan tersebut belum menunjukan angka yang besar, namun secara umum dapat dilihat bahwa metode Discovery Learning dapat membantu mahasiswa agar lebih kreatif dalam proses pembelajaran. Disebabkan karena keterbatasan waktu dalam penelitian sehingga peneliti belum mendapatkan hasil yang memuaskan seperti yang diharapkan.

Implikasi dari penelitian yang dilakukan dalam 2 siklus maka dapat disimpulkan bahwa yang mengalami peningkatan yaitu mencari dan menemukan masalah sendiri di lapangan, mengerjakan tugas rumah, berinisiatif mencatat keterangan dosen, membuat kesimpulan, tekun menjawab tugas, energik menanyakan materi yang tidak mengerti, berani mengeluarkan pendapat, berani bertanya kepada dosen, kritis memahami jawaban dari teman lain. Hal ini disebabkan karena:

1. Mahasiswa sudah memiliki bahan ajar

2. Sebagian mahasiswa sudah mengenal model pembelajaran yang digunakan

3. Sebagian mahasiswa sudah terlatih belajar dirumah, membaca materi yang akan dipelajari dam membuat rangkuman.

Yang belum mengalami peningkatan dengan baik yaitu: memperhatikan dosen yang sedang menerangkan, mendengarkan keterangan dosen. Hal ini disebabkan oleh:

1. Sebagian mahasiswa sering permisi keluar

2. Adanya mahasiswa yang saling ngobrol di kelas

3. Sebagian mahasiswa masih belum menguasai materi

Agar proses belajar mengajar dapat terlaksana dengan baik maka dilakukan penambahan tindakan baru yaitu Dosen menerangkan dan memberi penjelasan 
lebih jelas tentang materi yang dipelajari agar mahasiswa lebih mengerti dan memahami materi yang dipelajari tersebut. Mahasiswa diwajibkan membaca dirumah tentang materi yang akan dipelajari dan membuat ringkasan tentang materi tersebut. Mengumpulkan tugas - tugas yang telah diberikan, baik tugas diakhir pertemuan maupun tugas - tugas yang dikerjakan dirumah dan memberikan penilaian dari tugas - tugas tersebut.

Mengenai indikator kreatifitas belajar mahasiswa pada siklus I dan siklus II dapat dijabarkan sebagai berikut :

\section{Siklus I}

a. Kreatifitas belajar mahasiswa yang mengalami peningkatan diantaranya mencari dan menemukan sendiri masalah penelitian sosial dosen, mengerjakan tugas dirumah, berinisiatif mencatat kekurangan dosen, tekun mendengarkan keterangan dosen, tekun memperhatikan dosen yang sedang menerangkan, tekun menjawab soal latihan.

b. Kreatifitas belajar mahasiswa yang belum mengalami peningkatan diantaranya yaitu: membuat tugas individu, berinisiatif membuat kesimpulan, berani mengeluarkan pendapat, berani bertanya kepada dosen, energik menanyakan materi yang tidak mengerti, kritis dalam memahami jawaban teman.

\section{Siklus II}

a. Kreatifitas belajar mahasiswa yang mengalami peningkatan mencari dan menemukan masalah masalah di lapangan yang diberikan dosen, mengerjakan tugas dirumah, berinisiatif mencatat keterangan dosen, tekun mendengarkan keterangan dosen, tekun menjawab soal latihan, membuat tugas individu, berinisiatif membuat kesimpulan, berani mengeluarkan pendapat, berani bertanya kepada dosen, energik menanyakan materi yang tidak mengerti, kritis dalam memahami jawaban teman

b. Kreatifitas belajar mahasiswa yang belum mengalami peningkatan diantaranya yaitu : Tekun memperhatikan dosen yang sedang menerangkan

Secara keseluruhan dapat dilihat bahwa terjadi peningkatan kreatifitas mahasiswa pada tiap pertemuan. Dari pengamatan peneliti dan dosen mitra dapat disimpulkan bahwa dengan menggunakan metode Discovery Learning dapat meningkatkan kreatifitas mahasiswa dalam proses pembelajaran yang tercermin dalam proses pembelajaran.

\section{KESIMPULAN DAN SARAN}

Berdasarkan hasil penelitian dan pembahasan yg telah dilakukan, dapat disimpulkan bahwa penggunaan metode Discovery Learning dalam proses pembelajaran yg dilakukan pada siklus 1 dan 2 dapat meningkatkan kreatifitas belajar mahasiswa 2011 sesi C. Ditambah lagi dengan mahasiswa membaca buku metode penelitian serta membuat resume atau kesimpulan. Hal ini dapat dilihat melalui peningkatan 
keterlibatan mahasiswa selama proses pembelajaran berlangsung. Dengan menggunakan metode Discovery Learning, setiap mahasiswa mempunyai kesempatan yang sama untuk mengeluarkan pendapatnya masingmasing.

Berdasarkan hasil persentase kreatifitas belajar mahasiswa pada tiap siklus terjabar sebagai berikut: kreatif dalam mencari dan menemukan masalah di lapangan dengan persentase $59,15 \%$, tekun memperhatikan dosen menerangkan dengan persentase $89,05 \%$, tekun memperhatikan dosen yang sedang menerangkan dengan persentase $60,4 \%$, energik menanyakan materi yang tidak dimengerti dengan $35.8 \%$. berani mengeluarkan pendapat dengan persentase $53,15 \%$, berani bertanya kepada dosen dengan persentase $30.4 \%$ termasuk dalam kategori, kritis memahami jawaban dari teman lain dengan persentase $30.4 \%$.

Berdasarkan hasil penelitian dan pembahasan yang telah dilakukan, maka penulis dapat memberi saran sebagai berikut :

1. Ketua Program Studi Pendidikan Sejarah, supaya menyediakan bukubuku yg relefan di perpustakaan dengan mata kuliah yang disajikan,sehingga meempermudah mahasiswa untuk bahan kuliah.

2. Kepada Dosen, supaya mempersiapkan RPKPS yang terarah sebelum proses pembelajaran di lakukan serta menekankan kepada mahasiswa.
3. Bagi peneliti lain, mengingat penelitian ini hanya dilaksanakan sebanyak dua siklus, maka diharapkan kepada peneliti lain untuk melanjutkan dengan siklus berikutnya guna mendapatkan hasil yang lebih memuaskan.

\section{UCAPAN TERIMA KASIH}

Terbitnya tulisan ini tidak terlepas dari bantuan berbagai pihak, untuk itu penulis ucapkan terima kasih yang sebesar-basarnya kepada Pihak STKIP PGRI Sumatera Barat khususnya pengelola jurnal Pelangi yang telah memberikan kesempatan kepada penulis untuk menulis dijurnal Pelangi. Selanjutnya penulis juga berterima kasih kepada para penyumbang sumber insirasi yang telah memerikan inspirasi bagi penulis untuk mengutip atau menggunakan tulisannya sebagai bahan referensi.

\section{DAFTAR PUSTAKA}

Moh Dimyati, Mujiono. 1998. Strategi Belajar Mengajar, Jakarta : Depdikbud

Penelitian Tindakan Kelas (Classroom Action Research). (2006). Jakarta: Direktorat Pembina, Pendidikan Tenaga Kependidikan dan Perdosenan Tinggi 
Slameto. 2003. Belajar dan FaktorFaktor yang Mempengaruhi. Jakarta : Rineka Cipta

Wardani, Dkk. 2004. Penelitian Tindakan Kelas. Jakarta :UTD

Suharsimi Arikunto.,1989. Kriteria Penelitian Tindakan Kelas.Jakarta:Bumi Aksara.

Sardiman,1996. Interaksi Dan Motivasi Belajar Mengajar. Jakarta:PT.Radja grafindo

Sardiman A.M. (2007) Interaksi dan Motivasi Belajar Mengajar. Jakarta:PT Raja Grafindo Persada.

Oemar Hamalik (2008) Proses Belajar Mengajar. Jakarta : Bumi Aksara.

Mel Siberman, 2005, Active Learning: 101 Strategi Pembelajaran Aktif, Diterjemahkan oleh Sarjuli, dkk., Yogyakarta : Yapendis.

Roestiyah, 2001. Strategi Belajar Mengajar. Jakarta: Rineka Cipta

Winkel, W.S. (1996). Psikologi Pengajaran. Jakarta: Grasindo.

Zulfa dan Kaksim, 2013, Upaya Peningkatan Pemahaman Budaya Daerah Melalui CTL
Pada Mata Kuliah Sejarah Kebudayaan di Prodi Sejarah STKIP PGRI Sumbar, Padang: $\quad$ STKIP PGRI Sumbar. 